\title{
Effects of Test Temperature of Fatigue Damage Process of Austenitic Steels*
}

\author{
By Ken-ichi NISHIWAKI,** Toshio FUJITA ${ }^{* * *}$ and Yuichi SEKI ${ }^{* * * *}$
}

\section{Synopsis}

The temperature dependence of fatigue damage process was investigated using three austenitic steels, namely $\mathrm{Fe}-30 \mathrm{Ni}$ alloy which is metastable austenite, $\mathrm{Fe}-38 \mathrm{Ni}$ alloy which is stable austenite at room temperature and $\mathrm{Fe}-25 \mathrm{Ni}-16 \mathrm{Cr}$ alloy which has a low stacking fault energy of austenite.

The variation of plastic strain amplitude was measured at the temperatures of $100^{\circ} \mathrm{C}$ and $200^{\circ} \mathrm{C}$, and surface morphology and substructures were observed by optical and transmission electron microscopes. The main results obtained are as follows:

(1) The hardening tendency in metastable austenitic region results from the work hardening of austenite and formation of martensite, and the decrease of hardness is considered to be due to the tempering effect of martensite.

(2) The higher the stacking fault energy of austenite is, the more the hardening tendency is found, that is, this is attributed to the formation of the dislocation cells.

(3) Initial cracks are apt to occur mainly at grain boundaries in the case of high stress levels and at slip bands in the case of low stress levels. The rate of occurrence of cracks at slip bands is increased with the formation of surface striation.

\section{Introduction}

It is well-known that the fatigue damage process, which is the stage preceding the crack initiation process and generally shows fatigue hardening and softening, has a great effect on crack initiation sites and crack growth properties, with the advance of cyclic stress on metallic materials. The study of such cyclic plastic behavior as fatigue hardening and softening has been made by using mainly ferritic materials such as a pure iron ${ }^{1)}$ or low carbon annealed steels. ${ }^{2,3)}$ The substructure dislocation arrangements of them have been revealed to a great extent. ${ }^{1-3,5,6)}$

Besides, some investigations of austenitic materials were reported, and with an increase of recent demands those have been increasing. The authors reported $^{7)}$ the effect of strain induced martensite and stacking fault energy in fatigue process using three austenitic steels (Fe-30Ni, Fe-38Ni and $\mathrm{Fe}-25 \mathrm{Ni}-$ 16Cr). The fatigue damage of these austenitic steels is influenced to a great extent by the stabilization of austenite or the easiness of cross slips of screw dis- locations. Therefore, the study of the influence of them with changing the test temperature is of great importance.

In the present work, the influence of the austenite stabilization with increasing the test temperature has been studied, and the study of fatigue plastic behavior and the temperature dependence of dislocation arrangements after fatigue test has been made by the use of two austenitic steels which have different stacking fault energies (S.F.E.).

\section{Experimental Procedure}

\section{Specimen Preparation}

The chemical composition of specimens are given in Table 1. Fe-30Ni alloy has a metastable austenitic structure and shows clearly TRIP phenomenon at about room temperature. ${ }^{7)} \mathrm{Fe}-38 \mathrm{Ni}$ is an austenitic steel stable against the plastic deformation above room temperature. With the replacement of some nickel by chromium, Fe-25Ni-16Cr is aimed to have a low stacking fault energy of austenite and a similar stabilization, in Schaeffler's phase diagram, to that of $\mathrm{Fe}-38 \mathrm{Ni}$ steel.

All of the ingots were prepared by the aluminium deoxidation vacuum melting, and subsequently homogeneous-annealed at $1150^{\circ} \mathrm{C}$, where they were hotrolled to a plate of $6.0 \mathrm{~mm}$. Fatigue test specimens were machined from the plate as Fig. 1 and finished with mechanical and electro-polishing.

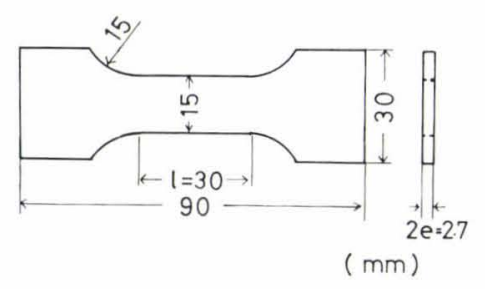

Fig. 1. Fatigue test specimen.

Table 1. Chemical composition of steels (wt \%).

\begin{tabular}{|c|c|c|c|c|c|c|c|c|c|}
\hline & $\mathrm{C}$ & $\mathrm{Si}$ & Mn & $\mathrm{P}$ & $\mathrm{S}$ & $\mathrm{Ni}$ & $\mathrm{Cr}$ & $\mathrm{Al}$ & $\mathrm{N}$ \\
\hline $\mathrm{Fe}-30 \mathrm{Ni}$ & 0.005 & 0.001 & 0.002 & 0.003 & 0.005 & 30.05 & - & 0.01 & 0.0015 \\
\hline $\mathrm{Fe}-38 \mathrm{Ni}$ & 0.003 & 0.001 & 0.002 & 0.003 & 0.005 & 37.80 & - & 0.01 & 0.0010 \\
\hline $\mathrm{Fe}-25 \mathrm{Ni}-16 \mathrm{Cr}$ & 0.005 & 0.001 & 0.004 & 0.003 & 0.014 & 24.71 & 15.92 & 0.03 & 0.0026 \\
\hline
\end{tabular}

* Originally published in Tetsu-to-Hagané, 65 (1979), 646, in Japanese. English version received May $11,1979$.

** Graduate School, The University of Tokyo, Hongo, Bunkyo-ku, Tokyo 113.

*** Department of Materials Science, Faculty of Engineering, The University of Tokyo.

**** Formerly Graduate School, The University of Tokyo. Now at Kobe Steel, Ltd., Wakinohama-cho, Fukiai-ku, Kobe 651. 


\section{Heat Treatment}

All the specimens were solution-treated for $1 \mathrm{hr}$, followed by furnace cooling. The average austenite grain sizes of $\mathrm{Fe}-30 \mathrm{Ni}, \mathrm{Fe}-38 \mathrm{Ni}$, and $\mathrm{Fe}-25 \mathrm{Ni}-16 \mathrm{Cr}$ were $36.5 \mu, 47.6 \mu$ and $33.1 \mu$, respectively, and $\mathrm{Ms}$ point of $\mathrm{Fe}-30 \mathrm{Ni}$ was $-20^{\circ} \mathrm{C}$. In $\mathrm{Fe}-38 \mathrm{Ni}$ and $\mathrm{Fe}-$ $25 \mathrm{Ni}-16 \mathrm{Cr}$, no martensite was observed even though at $-196^{\circ} \mathrm{C}$. Mechanical properties of these steels at $100^{\circ} \mathrm{C}$ and $200^{\circ} \mathrm{C}$ are given in Table 2 .

\section{Test Procedure}

Fatigue tests were performed under constant stress amplitude conditions in a Schenck bending fatigue tester. The tests were run at a frequency of 150 c.p.m. at a temperature of $100^{\circ} \mathrm{C}$ and $200^{\circ} \mathrm{C}$. The test temperature was controlled by the heating temperature of an electric furnace, which had been previously examined as a function of the temperature of specimens measured by a thermocouple spot-welded on them. The examination of fatigue hardening and softening on fatigue damage process has been assessed by the variation of plastic strain amplitude. The plastic strain amplitude $\varepsilon_{\mathrm{p}}$ is obtained as:

$$
\begin{aligned}
\varepsilon_{\mathrm{t}} & =\frac{2 e}{l} \tan \theta \ldots \ldots \ldots . . . \\
\theta & =a / 2 r \\
\varepsilon_{\mathrm{p}} & =\varepsilon_{\mathrm{t}}-\varepsilon_{\mathrm{e}} \\
& =\frac{2 e}{l} \tan \frac{\mathrm{a}}{2 r}-\frac{\sigma}{E}
\end{aligned}
$$

where, $\varepsilon_{\mathrm{t}}, \varepsilon_{\mathrm{e}}$ : total and elastic strain amplitudes, respectively

$l$ : a gage length of specimens

$e$ : a thickness of them

Table 2. Mechanical properties of steels.

\begin{tabular}{l|c|ccc}
\hline & & $\begin{array}{c}\text { U.T.S. } \\
\left(\mathrm{kg} / \mathrm{mm}^{2}\right)\end{array}$ & $\begin{array}{c}0.2 \% \text { P.S. } \\
\left(\mathrm{kg} / \mathrm{mm}^{2}\right)\end{array}$ & $\begin{array}{c}\text { Elongation } \\
(\%)\end{array}$ \\
\hline $\mathrm{Fe}-30 \mathrm{Ni}$ & $100^{\circ} \mathrm{C}$ & 38.4 & 12.9 & 38.5 \\
& $200^{\circ} \mathrm{C}$ & 36.5 & 10.7 & 39.0 \\
\hline $\mathrm{Fe}-38 \mathrm{Ni}$ & $100^{\circ} \mathrm{C}$ & 38.9 & 19.8 & 30.4 \\
& $200^{\circ} \mathrm{C}$ & 33.5 & 11.7 & 42.0 \\
\hline $\mathrm{Fe}-25 \mathrm{Ni}-16 \mathrm{Cr}$ & $100^{\circ} \mathrm{C}$ & 42.1 & 16.3 & 41.8 \\
& $200^{\circ} \mathrm{C}$ & 40.0 & 15.1 & 46.6 \\
\hline
\end{tabular}

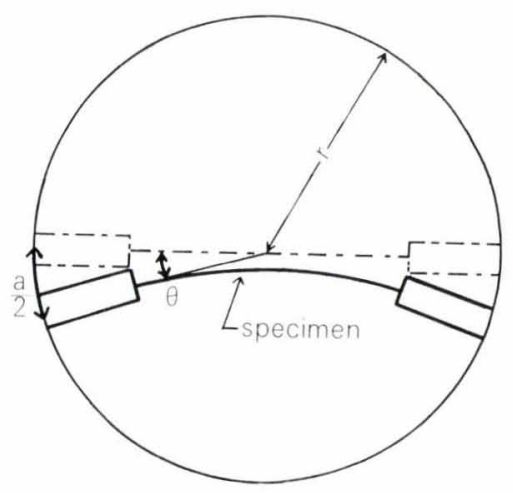

Fig. 2. Measurement of strains. $a, 0, r$ : shown in Fig. 2, which shows a maximum bending state.

Strain induced martensite amounts of $\mathrm{Fe}-30 \mathrm{Ni}$ during fatigue test were measured by X-ray diffraction.

Observations by an optical microscope have been made in order to reveal the initiation morphology of slip bands and micro-cracks with an increase in fatigue cycles. Moreover $150 \mathrm{kV}$ transmission electron microscopy (T.E.M.) has been employed to study microstructural behavior of dislocation arrangements changing with increasing fatigue cycles. As stress response values were changing as a function the depth from specimens surfaces, all the thin foils for T.E.M. were obtained at about $150 \mu$ depth from the surfaces, which had been first cut out to plates of about $1 \mathrm{~mm}$ thickness and subsequently processed with mechanical, chemical and electric polishing.

\section{Experimental Results}

\section{Fatigue Behavior at $100^{\circ} \mathrm{C}$}

The variation of plastic strain amplitude of $\mathrm{Fe}-$ $30 \mathrm{Ni}$ alloy under constant stress amplitudes (14 $25 \mathrm{~kg} / \mathrm{mm}^{2}$ ) at $100^{\circ} \mathrm{C}$ is given in Fig. 3. All the curves show a decrease in plastic strain amplitude, namely fatigue hardening, and with cracks initiating, show an apparent increase, followed by fracture. The hardening rate at a higher stress level is higher than those at lower ones. Moreover all the curves has a stage showing the tendency of saturation of the cyclic hardening, and the hardening rates at 25 and $20 \mathrm{~kg} /$ $\mathrm{mm}^{2}$ after these stages are clearly higher than before. As this is a metastable austenitic steel, martensite is induced with increasing in fatigue cycles as shown in Fig. 4. The inducing rates at low cycles at this temperature are higher than those at high cycles, as well as at room temperature. ${ }^{7)}$ And the induced martensite continues to be made gradually even at higher cycles. Even at the stress amplitude of $25 \mathrm{~kg} / \mathrm{mm}^{2}$ which showed exceedingly high strain amplitudes and a comparatively short fatigue lifetime as about $1.1 \times$ $10^{4}$ cycles, the volume percentage of strain induced martensite at fracture is only $15 \%$ and still less than that at room temperature. Transmission electron

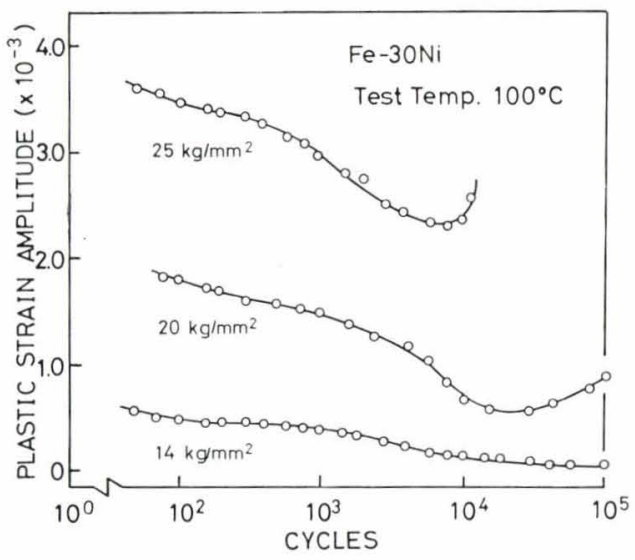

Fig. 3. Variation of plastic strain amplitude during testing: $\mathrm{Fe}-30 \mathrm{Ni}, \mathrm{T}=100^{\circ} \mathrm{C}$. 
microscopy revealed that all the induced martensites are of lath-type as shown in Photo. 1 (a) and that the dislocation cell structure is observed in austenite (Photo. 1 (b)).

The variation of plastic strain amplitude of $\mathrm{Fe}-$ $38 \mathrm{Ni}$ at $100^{\circ} \mathrm{C}$ is given in Fig. 5. In this steel, $0.2 \%$ proof stress at $100^{\circ} \mathrm{C}$ was $19.8 \mathrm{~kg} / \mathrm{mm}^{2}$ and much larger than that of $\mathrm{Fe}-30 \mathrm{Ni} 12 \mathrm{~kg} / \mathrm{mm}^{2}$; therefore, plastic strain amplitude values are wholly less than those of $\mathrm{Fe}-30 \mathrm{Ni}$. However, all the curves show the fatigue hardening tendency as that in $\mathrm{Fe}-30 \mathrm{Ni}$. Besides, the saturation stage as seen in $\mathrm{Fe}-30 \mathrm{Ni}$ is present only for $27 \mathrm{~kg} / \mathrm{mm}^{2}$ stress amplitude. As shown in Photo. 1 (c), fairly remarkable dislocation cell structure is formed in this steel.

The variation of plastic strain amplitude of $\mathrm{Fe}-$ $25 \mathrm{Ni}-16 \mathrm{Cr}$ is given in Fig. 6. It is found with this steel that the deformation behavior is different from that of the former two steels. The strain amplitude of $25 \mathrm{~kg} / \mathrm{mm}^{2}$ has a tendency to present a gradual softening as increasing cycles and a little hardening before fractures. However, at $22 \mathrm{~kg} / \mathrm{mm}^{2}$ and $20 \mathrm{~kg} /$ $\mathrm{mm}^{2}$, the hardening tendency is shown. In case of $14 \mathrm{~kg} / \mathrm{mm}^{2}$, the softening tendency is provided and then the hardening can be found. Transmission

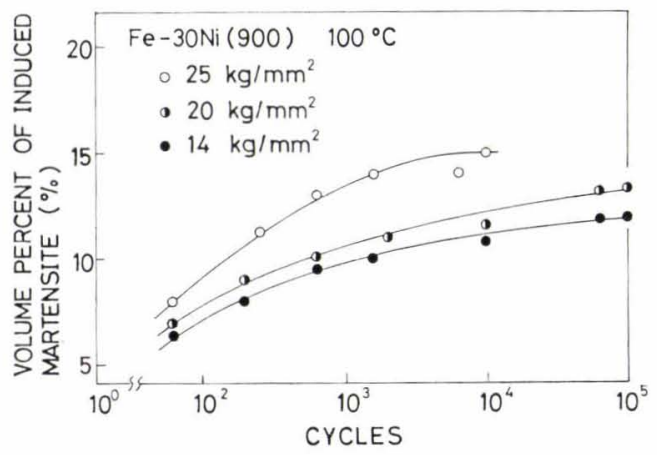

Fig. 4. Change of the volume fraction of martensite during testing: $\mathrm{Fe}-30 \mathrm{Ni}(900)$ micrograph of this steel after fatigue test is given in Photo. 1 (d).

\section{Fatigue Behavior at $200^{\circ} \mathrm{C}$}

The variation of plastic strain amplitude of $\mathrm{Fe}-$ $30 \mathrm{Ni}$ at $200^{\circ} \mathrm{C}$ is given in Fig. 7. It is seen that the gradual hardening occurs from the initial cycles and that the hardening rate increases with increasing

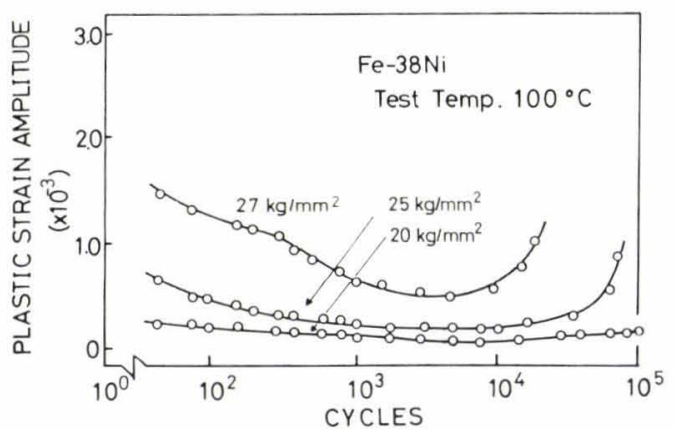

Fig. 5. Variation of plastic strain amplitude during testing: $\mathrm{Fe}-38 \mathrm{Ni}, T=100^{\circ} \mathrm{C}$.

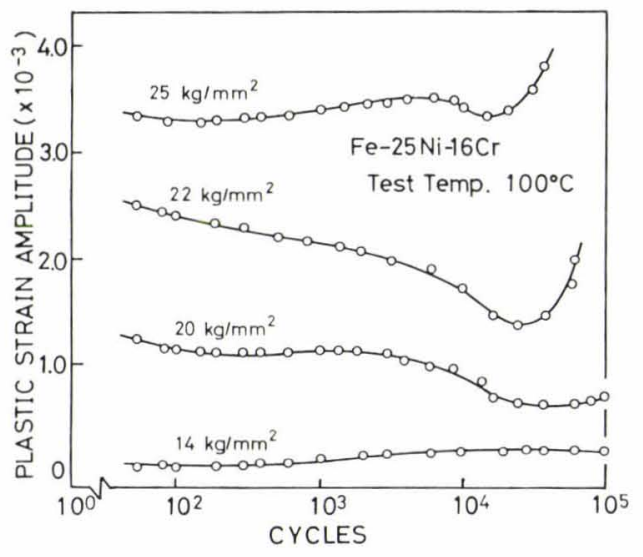

Fig. 6. Variation of plastic strain amplitude during testing: $\mathrm{Fe}-25 \mathrm{Ni}-16 \mathrm{Cr}, T=100^{\circ} \mathrm{C}$.
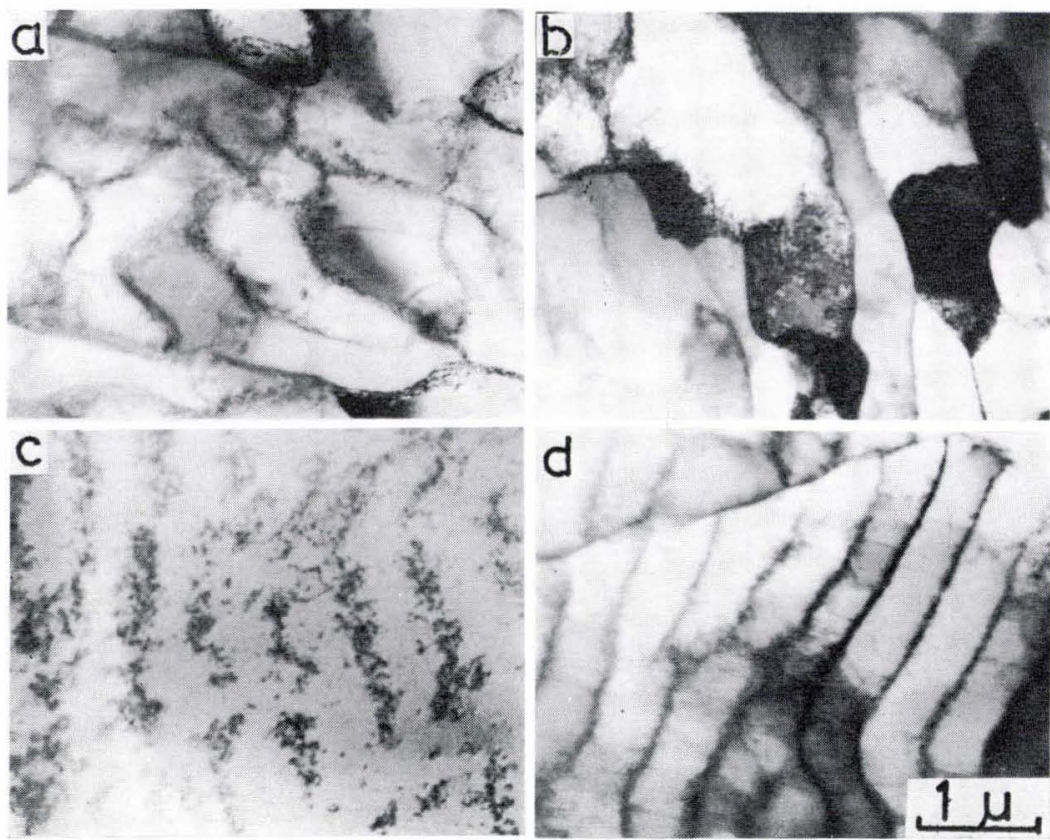

a: $\mathrm{Fe}-30 \mathrm{Ni}$ (Induced martensite); $\sigma_{a}=20 \mathrm{~kg} / \mathrm{mm}^{2}$

b: $\mathrm{Fe}-30 \mathrm{Ni}$ (Austenite); $\sigma_{a}=20 \mathrm{~kg} / \mathrm{mm}^{2}$

c: $\mathrm{Fe}-38 \mathrm{Ni} ; \sigma_{a}=25 \mathrm{~kg} / \mathrm{mm}^{2}$

$\mathrm{d}$ : $\mathrm{Fe}-25 \mathrm{Ni}-16 \mathrm{Cr} ; \sigma_{a}=25 \mathrm{~kg} / \mathrm{mm}^{2}$

Photo. 1. Transmission electron micrographs of specimens fatigued to failure at $100^{\circ} \mathrm{C}$. 
cycles. Besides, any induced martensite was not observed at this temperature.

The cases of $\mathrm{Fe}-38 \mathrm{Ni}$ and $\mathrm{Fe}-25 \mathrm{Ni}-16 \mathrm{Cr}$ are given in Figs. 8 and 9, respectively. Both stecls exhibit initial hardening, and subsequently a saturation or a slight softening stage is found, followed by a secondary hardening stage before the fracture.

Transmission micrographs revealed that a welldeveloped dislocation cell structure was formed in each steel, as shown in Photo. 2.

\section{Surface Morphology}

Surface morphology at $100^{\circ} \mathrm{C}$ after fatigue test is given in Photo. 3. For all the steels, especially in higher stress levels, marked progressive surface saturation of slip bands was observed. In high stress levels, a great number of cracks were formed along grain boundaries; however, this tendency was not so remarkable as that at room temperature. For example, in case of $30 \mathrm{~kg} / \mathrm{mm}^{2}$ stress level for $\mathrm{Fe}-30 \mathrm{Ni}$ (lifetime: 3700 cycles) and $\mathrm{Fe}-38 \mathrm{Ni}$ (4 100 cycles), they were formed frequently at slip lines. Besides, in case of low stress level, almost all the cracks were intiated at slip lines, but they were not formed at

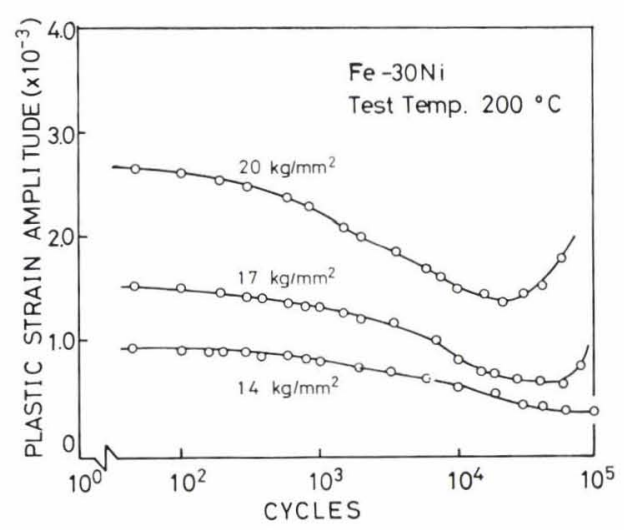

Fig. 7. Variation of plastic strain amplitude during testing: $\mathrm{Fe}-30 \mathrm{Ni}, \mathrm{T}=200^{\circ} \mathrm{C}$. martensite-austenite boundaries. The morphology at $200^{\circ} \mathrm{C}$ is given in Photo. 4. Even at a fairly low stress level, for all the steels, marked striations were observed at this temperature. Initial cracks were mainly formed along the striations and increased to be formed at grain boundaries with increasing in the stress level.

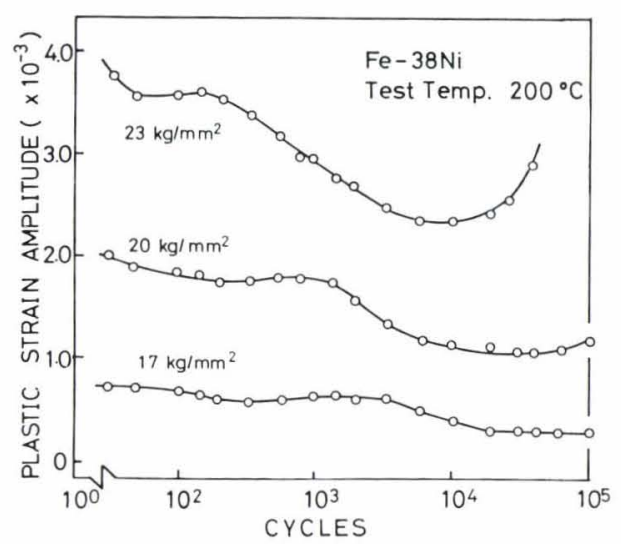

Fig. 8. Variation of plastic strain amplitude during testing: $\mathrm{Fe}-38 \mathrm{Ni}, \mathrm{T}=200^{\circ} \mathrm{C}$.

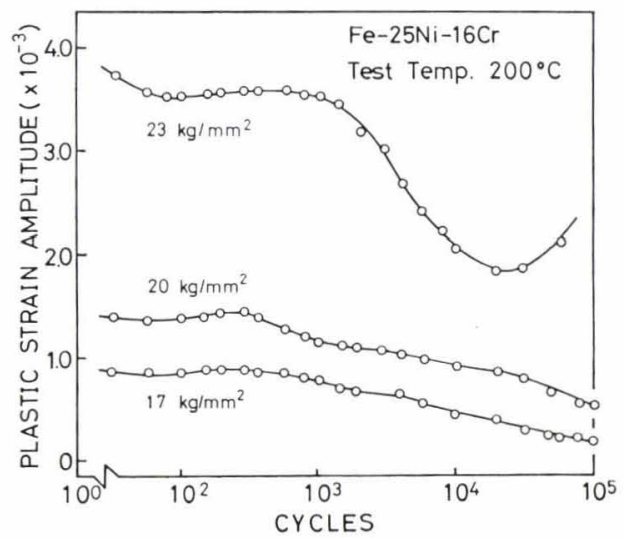

Fig. 9. Variation of plastic strain amplitude during testing: $\mathrm{Fe}-25 \mathrm{Ni}-16 \mathrm{Cr}, \mathrm{T}=200^{\circ} \mathrm{C}$. a: $\mathrm{Fe}-30 \mathrm{Ni} ; \quad \sigma_{a}=17 \mathrm{~kg} / \mathrm{mm}^{2}$, to failure

b: $\mathrm{Fe}-38 \mathrm{Ni} ; \quad \sigma_{a}=20 \mathrm{~kg} / \mathrm{mm}^{2}$, to failure

c: $\mathrm{Fe}-38 \mathrm{Ni} ; \sigma_{a}=20 \mathrm{~kg} / \mathrm{mm}^{2}$, after $10^{3}$ cycles

d: $\mathrm{Fe}-25 \mathrm{Ni}-16 \mathrm{Cr} ; \sigma_{a}=20 \mathrm{~kg} / \mathrm{mm}^{2}$, to failure

Photo. 2. Transmission electron micrographs of specimens fatigued at $200^{\circ} \mathrm{C}$.
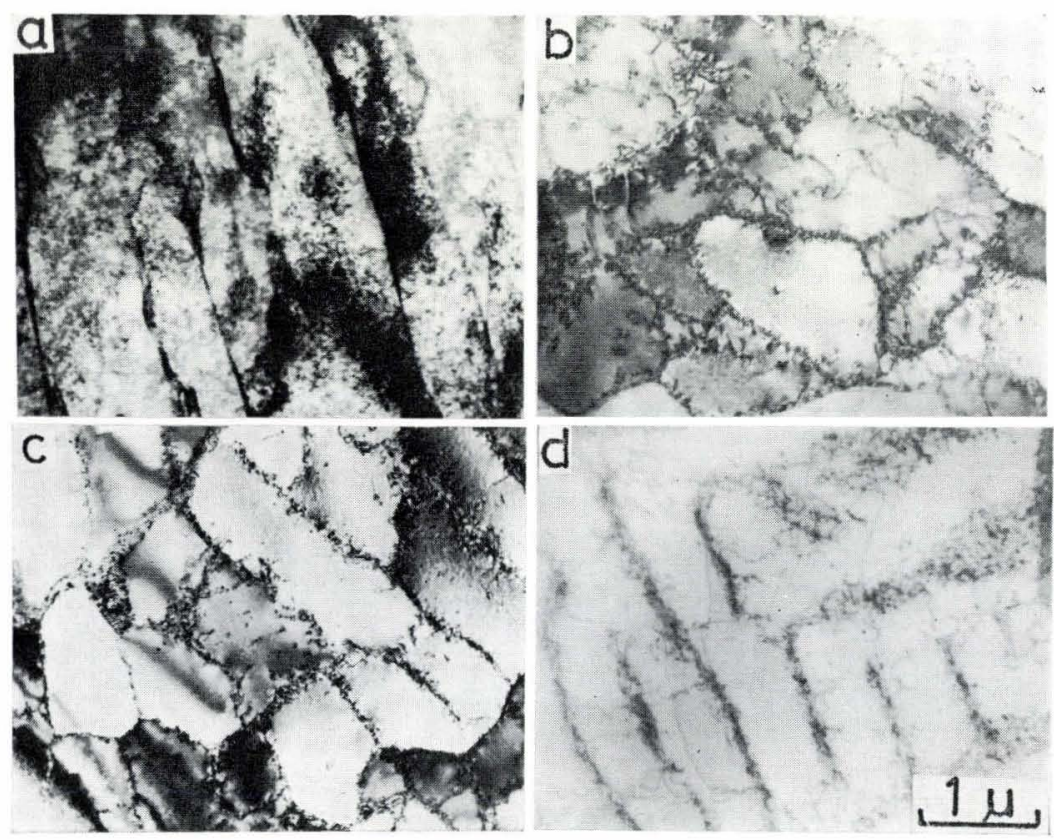

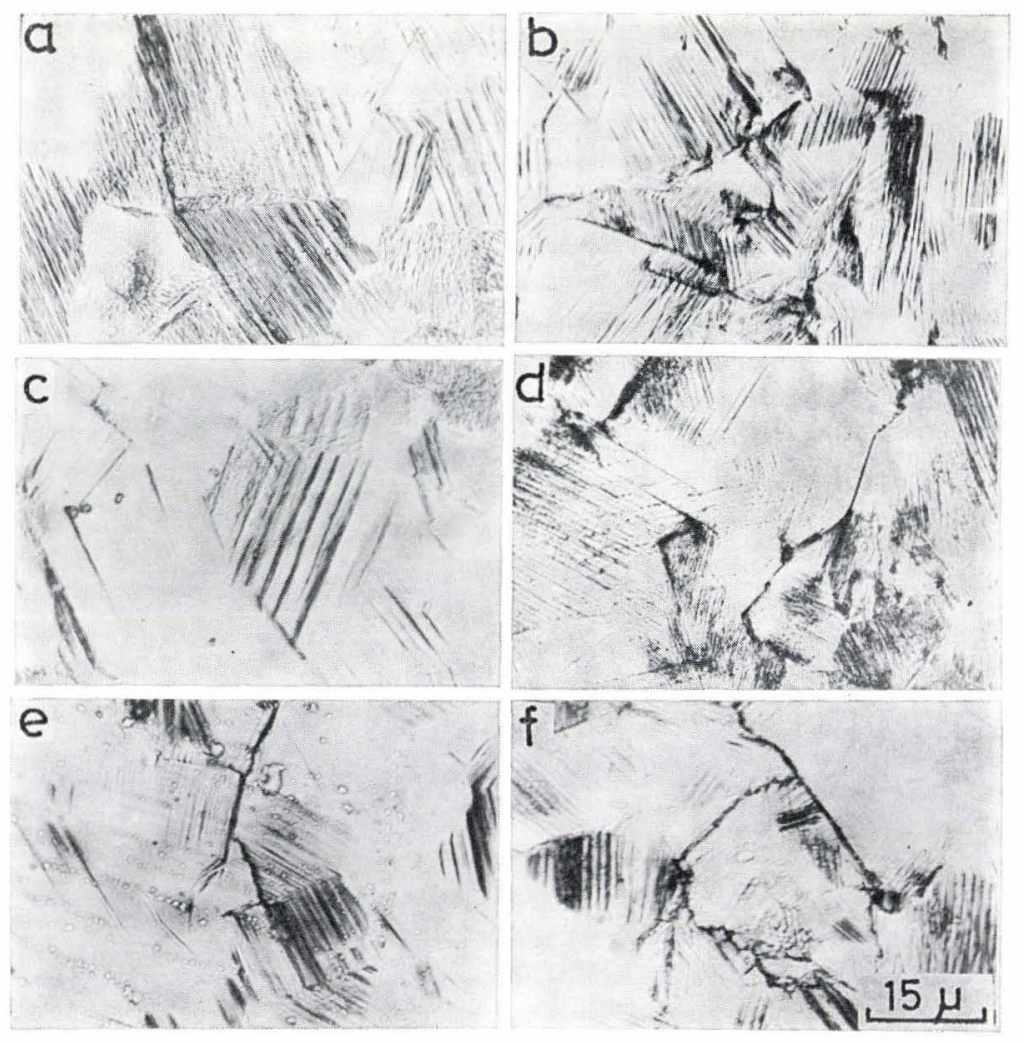

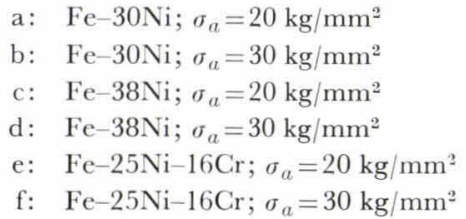

Photo. 3. Slip bands and fatigue cracks on the surface of specimens fatigued at $100^{\circ} \mathrm{C}$. a: $\mathrm{Fe}-30 \mathrm{Ni} ; \sigma_{a}=17 \mathrm{~kg} / \mathrm{mm}^{2}$

b: $\mathrm{Fe}-30 \mathrm{Ni} ; \sigma_{a}=27 \mathrm{~kg} / \mathrm{mm}^{2}$

c: $\mathrm{Fe}-38 \mathrm{Ni} ; \sigma_{a}=17 \mathrm{~kg} / \mathrm{mm}^{2}$

$\mathrm{d}$ : $\mathrm{Fe}-38 \mathrm{Ni} ; \sigma_{a}=27 \mathrm{~kg} / \mathrm{mm}^{2}$

e: $\mathrm{Fe}-25 \mathrm{Ni}-16 \mathrm{Cr} ; \sigma_{a}=17 \mathrm{~kg} / \mathrm{mm}^{2}$

f: $\mathrm{Fe}-25 \mathrm{Ni}-16 \mathrm{Cr} ; \sigma_{a}=27 \mathrm{~kg} / \mathrm{mm}^{2}$

Photo. 4. Slip bands and fatigue cracks on the surface of specimens fatigued at $200^{\circ} \mathrm{C}$.

\section{Discussion}

1. Effects of a Temperature of $100^{\circ} \mathrm{C}$ on Fatigue Damage Process of $\mathrm{Fe}-30 \mathrm{Ni}$ Alloy

$\mathrm{Fe}-30 \mathrm{Ni}$ alloy has a tendency to rapid cyclic hardening in initial cycles at room temperature, this is attributed to the formation of induced martensite. ${ }^{7}$ Besides, even at $100^{\circ} \mathrm{C}$, as this steel is still a metastable
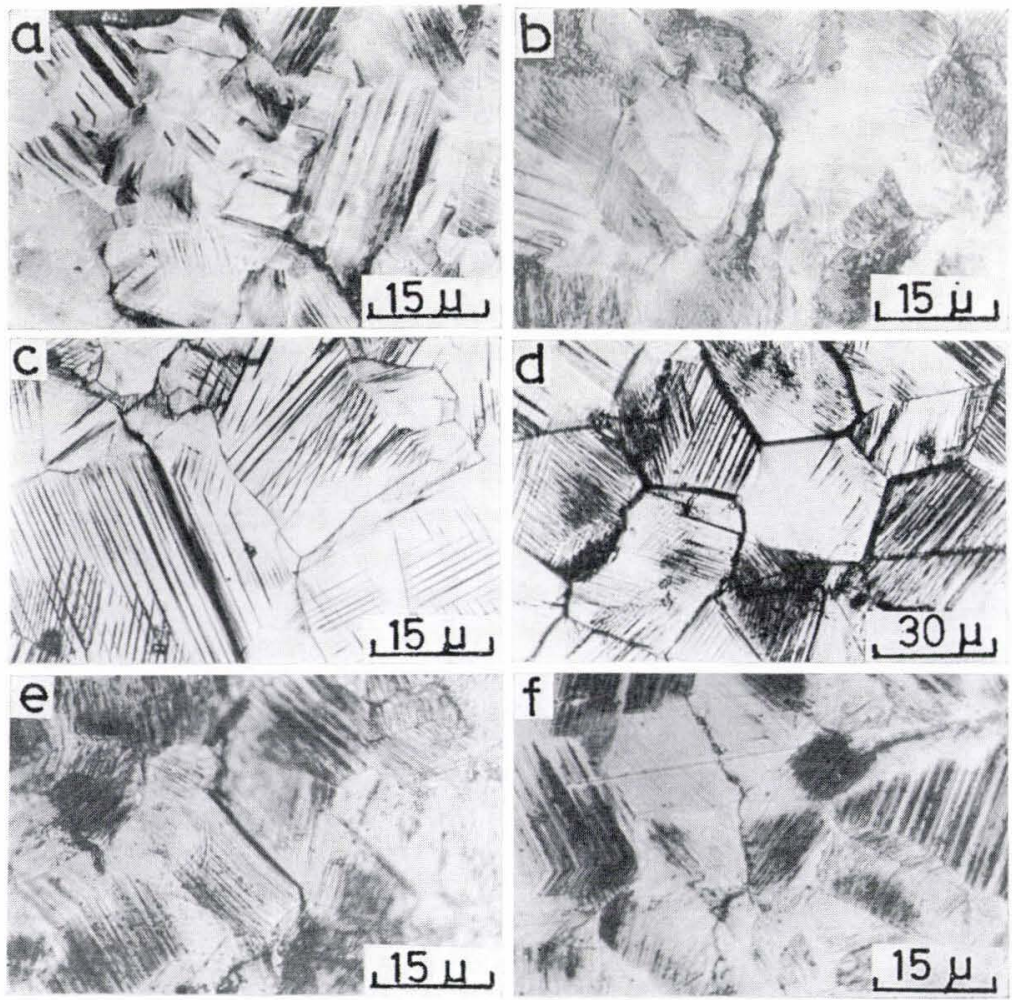

austenite, martensite is induced with increasing in cycles. However, the amount of induced martensite is much less than that at room temperature; therefore, its formation behavior does not always agree with the deformation behavior. Therefore, the cause of the cyclic hardening of $\mathrm{Fe}-30 \mathrm{Ni}$ appears to be influenced by some other factors. In order to reveal this point, microhardness of the austenite at $20 \mathrm{~kg} / \mathrm{mm}^{2}$ stress 
level and the martensite induced up to 77 cycles has been measured. At this time, the tester was stopped at 77 cycles, and the martensite induced up to 77 cycles was colored by $30 \% \mathrm{NaHSO}_{3}$ solution and distinguished from the subsequently formed martensite. The result is given in Fig. 10. It is seen that the martensite shows a tendency of rapid hardening until 200 cycles and then softening until about 6000 cycles, followed by hardening. This hardening and softening can be explained in terms of the relationship between the dislocations formed by martensite transformation and those introduced by cyclic deformation, that is, work-hardening and re-arrangement of these dislocations. The saturation stage of plastic strain amplitude appears to be made by temper softening of martensite on account of the agreement of fatigue cycles and softening stage of the martensite. Besides, the austenite has a tendency to gradual hardening as shown in the solid line of Fig. 10, while marked striations are locally formed at later cycles, and in the regions the austenite has a softening tendency as shown in the dotted line. Therefore, in this steel it is concluded that work-hardening not only by the formation of martensite but also of martensite and austenite themselves causes the decrease in plastic strain amplitude. Moreover dislocation cells also operate on it, and the details will be presented in the next section. Though the softening in austenite cannot be revealed by the measurement of microhardness, i.e., whether it does not occur at all or it is not clear because of some other hardening factors, striations formed at surface obviously cause softening of austenite.

\section{Effects of Test Temperature on Fatigue Damage of Stable Austenitic Steels}

In $\mathrm{Fe}-38 \mathrm{Ni}$ alloy which is stable austenite steel and has fairly high S.F.E., it is observed that dislocation cells are formed especially at grain boundaries at room temperature and that with rising test temperature they are formed gradually in grains. Besides, $\mathrm{Fe}-30 \mathrm{Ni}$ and $\mathrm{Fe}-25 \mathrm{Ni}-16 \mathrm{Cr}$ which donot form dislocation cells at room temperature are liable to form the cells or sub-boundaries with a rise in test temperature. L. A. James and E. B. Schwenk ${ }^{9)}$ and Hatanaka et al. ${ }^{10)}$ also reported the similar result which was assessed at

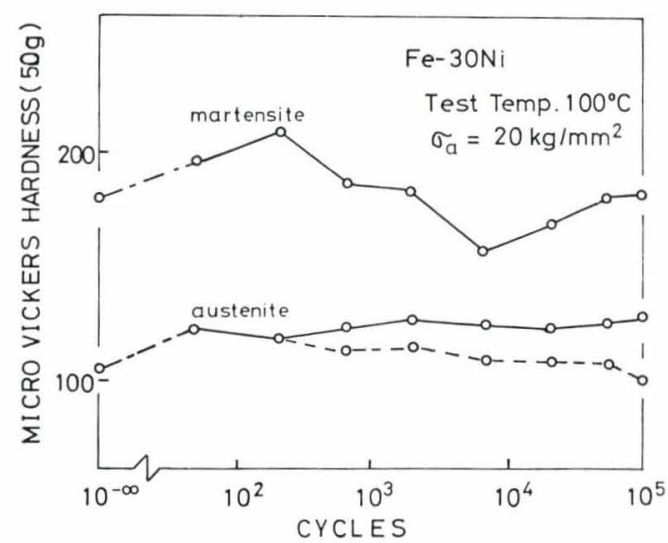

Fig. 10. Variation of microhardness during testing: $\mathrm{Fe}-$ $30 \mathrm{Ni}, \mathrm{T}=100^{\circ} \mathrm{C}$. cross slips of screw dislocations and active rising movement of dislocations. These cells, which prevent dislocations from moving smoothly because of increase in dislocation densities, is attributed to fatigue hardening at such a temperature. The deformation process of $\mathrm{Fe}-38 \mathrm{Ni}$ alloy at $200^{\circ} \mathrm{C}$ is divided into: 1) hardening stage in initial cycles, 2) saturation stage of that hardening, and 3) subsequent hardening stage. The initial hardening is attributed to work-hardening due to introduced dislocations. The saturation stage of the hardening might have softening on account of rearrangement ${ }^{11}$ ) of initial introduced dislocations. Moreover in this stage the cells are formed partially and subsequently hardening stage turns up as developing of these cells (Photo. 2 (c)). The saturation stage in low stress level turning to high cycle number makes the formation of the cells in low stress level to the high cycle number.

$\mathrm{Fe}-30 \mathrm{Ni}$ at $200^{\circ} \mathrm{C}$ and $\mathrm{Fe}-38 \mathrm{Ni}$ at $100^{\circ} \mathrm{C}$, in which marked saturation stage is not found, do not have microscopically the saturation of the hardening because of continuous formation of cells by initially introduced dislocations.

\section{Influence of Stacking Fault Energy (S.F.E.)}

Fe-25Ni-16Cr with low S.F.E. at room temperature $^{7)}$ showed cyclic hardening tendency and liner dislocation arrangements. However in case of $100^{\circ} \mathrm{C}$, extremely complicated deformation behavior was observed in accordance with each stress level. Though initial softening shown in the highest stress level $(25 \mathrm{~kg} /$ $\mathrm{mm}^{2}$ ) which progressed extremely gradually could not be made clear, remarkable surface striations as well as micro-cracks appeared to be attributed to the softening. Therefore cyclic hardening was noticed when the striations were not so well formed $\left(22 \mathrm{~kg} / \mathrm{mm}^{2}\right.$, $20 \mathrm{~kg} / \mathrm{mm}^{2}$ ). The fact that cyclic softening began to appear with reducing stress levels is similar to the result of Fe-38Ni alloy with low S.F.E., cross slips of screw dislocations and climbing movement of dislocations were easy to occur with raising temperature, when the softening can be explained in terms of increase of mobile dislocation densities ${ }^{1)}$ and re-arrangement of introduced dislocations. ${ }^{11)}$ In case of $200^{\circ} \mathrm{C}$, the cause of this softening is more obvious and the deformation behavior in the lower stress level has a similar tendency to that of $\mathrm{Fe}-38 \mathrm{Ni}$ as described in VI. 2. Therefore at elevated temperature this material with low S.F.E. lose the feature as shown at room temperature.

\section{Fatigue Crack Initiation}

Initial cracks are apt to occur mainly grain boundaries in case of high stress levels and at slip bands in case of low ones, this is not more marked than that at room temperature. ${ }^{7)}$ As the formation of surface striation proceeds and then the stress concentrates there with raising the test temperature, initial cracks are liable to be formed at slip bands even in high stress levels. Initial cracks at martensite-austenite boundaries in $\mathrm{Fe}-30 \mathrm{Ni}$, in the same way, extremely decrease even in low stress levels. 


\section{Conclusion}

The effects of temperature dependence on fatigue damage process was investigated using a metastable austenite steel (Fe-30Ni alloy) and stable austenitic steels (Fe-38Ni alloy and $\mathrm{Fe}-25 \mathrm{Ni}-16 \mathrm{Cr}$ alloy which have different S.F.E.'s). Main results are as follows:

(1) In $\mathrm{Fe}-30 \mathrm{Ni}$ alloy at $100^{\circ} \mathrm{C}$ cyclic hardening tendency existed generally, but partially the saturation stage of the hardening was present.

(2) This hardening was attributed to not only the formation of martensite but work-hardening of martensite and austenite itself. Besides, the saturation appeared to cause softening of martensite.

(3) Remarkable hardening was found in $\mathrm{Fe}-$ $38 \mathrm{Ni}$ alloy with high S.F.E. as rising temperature and attributed to the formation of dislocation cells.

(4) The deformation behavior of $\mathrm{Fe}-25 \mathrm{Ni}-16 \mathrm{Cr}$ alloy with low S.F.E. at $100^{\circ} \mathrm{C}$ was similar to that of $\mathrm{Fe}-38 \mathrm{Ni}$ alloy at room temperature.

(5) Initial cracks are apt to occur mainly at grain boundaries in high stress levels and at slip bands in low ones, at each test temperature, and the ratio of cracks at slip bands increases with the formation of surface striation.

\section{REFERENCES}

1) F. U. Lawrennce, Jr. and R. C. Jones: Met. Trans., 1 (1970), 367.

2) M. Klesnie, M. Holzmann, P. Lukas and P. Rys: JISI, 203 (1965), 47.

3) M. Klesnie and P. Lukas: JISI, 205 (1967), 746.

4) M. Kikukawa, M. Shirono and T. Sou: Zairyo, 21 (1972), 753.

5) S. Horibe, R. Sagawa, T. Fujita and T. Araki: Tetsu-toHagané, 64 (1978), 268.

6) J. McGrath and W. T. Bratina: Phil. May., 11 (1865), 429.

7) S. Horibe, Y. Seki, T. Fujita and T. Araki: Tetsu-toHagané, 64 (1978), 278.

8) P. Beardmore and C. F. Feltner: Proc. 2nd Int. Conf. Fracture, Chapman and Hall, London, (1969), 607.

9) L. A. James and E. B. Schwenk, Jr.: Met. Trans., 2 (1971), 491.

10) K. Hatanaka, H. Kawabe and T. Yamada: Zairyo, 20 (1971), 481.

11) C. E. Feltner and C. Laind: Acta Met., 15 (1967), 1633. 